\title{
Siew New Disease Reports \\ First report of Botrytis cinerea causing grey mould disease of bush basil in Korea
}

W. Dumin, Y.H Seo, M.J Park, J.H Park and C.G Back*

Horticultural and Herbal Crop Environment Division, National Institute of Horticultural and Herbal Science, Rural

Development Administration, Wanju 55365, Republic of Korea

*E-mail: plantdoctor7@korea.kr

Received: 14 Apr 2020. Published: 08 Jun 2020. Keywords: fungal pathogen, Ocimum minimum, Yongin

In Korea, bush basil (Ocimum minimum) is more popular as an ornamental plant than a culinary herb. However, bush basil is not native to Korea and most of the commercially cultivated plants are imported from The Netherlands. In February 2018, approximately $40 \%$ of the bush basil cultivated in a greenhouse in Yongin $\left(37^{\circ} 05^{\prime} 56.6^{\prime \prime} \mathrm{N} 127^{\circ} 08^{\prime} 27.0^{\prime \prime} \mathrm{E}\right)$ showed symptoms of grey mould disease initiating from the stem and young leaf tissues. As the disease progressed, leaves on the infected branch withered (Fig. 1) and infection of the main stem resulted in the death of the entire plant.

To identify the causal agent, small pieces of symptomatic tissues from the infected plants were excised and sterilised with $1 \%$ sodium hypochlorite solution for 1 minute, rinsed three times with sterile distilled water before transfer to potato dextrose agar plates. Inoculated plates were incubated at $22 \pm 2^{\circ} \mathrm{C}$ for five days in the dark. For morphological identification, five fungal isolates were examined. Fungal colonies observed on agar were initially white but later turned grey to brown after seven days incubation (Fig. 2). Conidia were hyaline, mostly ellipsoid or ovoid in shape and sized between 8.2-16.5 × 5.4-9.3 $\mu \mathrm{m}$ (average size $7.5 \times 10.8 \mu \mathrm{m}, \mathrm{n}=100$ ), whereas conidiophores appeared straight or flexuous, septate, branched at the upper part, and each branch end with spherical swelling bearing cluster of conidia (Fig. 3).

A pathogenicity test was performed twice by spraying a conidial suspension $\left(1 \times 10^{6}\right.$ conidia/ml $)$ of the fungal pathogen directly on plants. For each pathogenicity test, eight pot-grown bush basil plants were used. Five plants were inoculated with the conidial suspension and the other three were mockinoculated with sterile water as a control. Inoculated and control plants were covered with a plastic bag to maintain $100 \%$ relative humidity environment and held at $22-25^{\circ} \mathrm{C}$. Twenty-four hours after inoculation, plants were uncovered and left in the greenhouse for another seven days at $22^{\circ} \mathrm{C}$. Typical disease symptoms appeared four days post-inoculation on the inoculated plant but not on the control. Disease symptoms observed were similar to the naturally infected plants as described above (Fig. 4). The isolated fungal pathogen also showed an identical morphology to the original isolates thus fulfilling Koch's postulates.

Molecular identification was performed based on the sequence comparisons of internal transcribed spacer (ITS) and nuclear protein-coding genes (RPB2, HSP60 and G3PDH) (White et al., 1990; Staats et al., 2005). BLAST analysis showed that the amplified nucleotide sequences of G3PDH, HSP60, RPB2 and ITS are 99 to $100 \%$ identical to the respective reference genes (MK791186, AB971650, MK79118 and KU992696) previously identified in Botrytis cinerea. All sequences were deposited in the GenBank under Accession Nos LC519319 to LC519322.

Identification of Botrytis cinerea as a causal agent of grey mould disease provides us with vital knowledge to implement disease management strategies to minimise the loss of bush basil production in Korea. Although Botrytis cinerea infection in sweet basil (Ocimum basilicum) has been reported by Aktaruzzaman (2015), to our knowledge, this is the first report of Botrytis cinerea infection in bush basil (Ocimum minimum) in Korea and worldwide.

\section{Acknowledgements}

This work was carried out with the support of the "Cooperative Research Program for Agriculture Science \& Technology Development (Project No. PJ015090501), Rural Development Administration, Republic of Korea.

\section{References}

1. Aktaruzzaman M, Kim J-Y, Afroz T, Hong S-J, Kim B-S, 2015. First report of gray mold disease of sweet basil (Ocimum basilicum) caused by Botrytis cinerea in Korea. The Korean Journal of Mycology 43, 277-280. http://dx.doi.org/10.4489/KJM.2015.43.4.277

2. Staats M, van Baarlen P, van Kan JAL, 2005. Molecular phylogeny of the plant pathogenic genus Botrytis and the evolution of host specificity. Molecular Biology and Evolution 22, 333-346. http://dx.doi.org/10.1093/molbev/msi020

3. White TJ, Bruns T, Lee S, Taylor J, 1990. Amplification and direct sequencing of fungal ribosomal RNA genes for phylogenetics. In: Innis MA, Gelfand DH, Sninsky JJ, White TJ, eds. PCR Protocols: A Guide to Methods and Applications. San Diego, CA, USA: Academic Press, 315-322. http://dx.doi.org/10.1016/B978-0-12-372180-8.50042-1

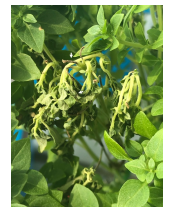

Figure 1

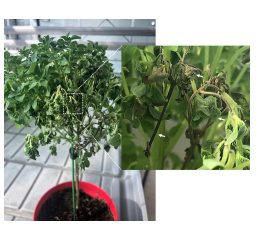

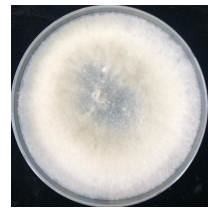

Figure 2

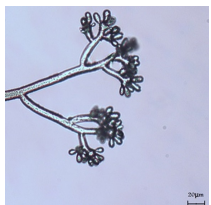

Figure 3

Figure 4

To cite this report: Dumin W, Seo YH, Park MJ, Park JH, Back CG, 2020. First report of Botrytis cinerea causing grey mould disease of bush basil in Korea. New Disease Reports 41, 33. http://dx.doi.org/10.5197/j.2044-0588.2020.041.033

(c) 2020 The Authors

This report was published on-line at www.ndrs.org.uk where high quality versions of the figures can be found. 